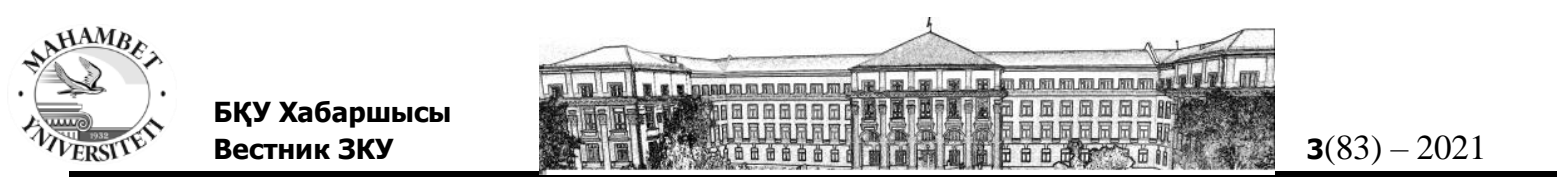

UDC 372.881.111.1

IRSTI 14.07.07

DOI 10.37238/1680-0761.2021.83(3).7

\author{
Nurkasheva Fariza* \\ Makhambet Utemisov West Kazakhstan University, Uralsk, Kazakhstan \\ *Correspondence: fariza.nurkasheva@mail.ru
}

E-mail: fariza.nurkasheva@mail.ru

\title{
THE IMPORTANCE OF COMPUTER TECHNOLOGY IN LEARNING ENGLISH IN DISTANCE LEARNING FORMAT
}

\begin{abstract}
Annotation. The distance learning process is the main direction around the world. Currently, the question of the effective organization of distance education and achieving certain results in this directions is very relevant. The article studied the importance of the formation of skills and competence in teaching English in the process of distance learning. The advantages of informationcommunication tools in language learning are shown. The main components of distance learning are summarized and the properties of computer technologies are considered for efficient teaching. The concept of monitoring and its importance is specified during distance learning and its great importance for high school students in self-esteem. Differentiated lessons and their results on training platforms in the distance learning process. Reviews and features of effective computer programs in language teaching have proved.
\end{abstract}

Keywords: distance learning, e-learning technologies, electronic resources, monitoring, training platforms.

\section{Introduction}

World pandemic has led to radical changes in the field of education. One of them is a unique format - distance learning. Teaching foreign language according to students' features, one of the current today's problems. The distance learning system allows you to use several ways and tools at the same time. It ensures the student's self-assessment and independent work. In distance learning space among teachers and listeners, a significant part of the educational process is performed through information and telecommunications equipment. Distance learning of English via the Internet is a significant part of the study material using technical software, administrative network. In this regard, distance learning is a great help to improve the work of the teacher in controlling the level of knowledge of the student.

In distance learning format students learn to justify structural and logical schedules to analyze the textbook on the topic for the theme using virtual lessons, independent work, seminars, e-mails.

Research materials and methods

In the analysis of scientific literature, we found out that the use of distance learning technologies in the field of education have been provided in several areas of research of foreign and domestic scientists. For example, aspects of the use of information technology in the distance learning process are philosophically analyzed in detail in the works of E.K. Balafanov E.E Esbosynov, Zh.A. Karayev [1, p. 148]. The general pedagogical bases of the distance learning process and all contents are systematized in the works of V.F. Dmitreva, VI Gladskoy V.A. Ryabov [2, p. 36-39].

According to A.A. Andreev and V.I. Soldatkin distance learning is a targeted and organized form of teaching using interactive teaching aids [3, p. 48]. In addition, A.A. Andreev emphasized in 


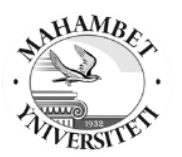

his works that distance learning is a form of education by using traditional and specific types of teaching through telecommunication and computer technologies [4, p. 196].

Due to the content and purpose of training, the importance of the computer is offered by various computer programs due to various systematization of the training program, the mains are:

Exercise-teacher, problematic simulated modeling, games, observer (tester), text editors [5, $\mathrm{p}$. 143].

Game and simulated modeling programs are used to replenish modeling, computer service as part of a communication partner, as well as used as an organizer and implementer of dialogue between students in the process of learning. In order to increase the influence of the computer in the language communication, the use of it with a tape recorder gives a positive effect. Computer programs are self-employed and very useful in self-work of students and widely used in classroom work, when teacher is a continuing person between students and e-learning [6, p. 369-375].

With the help of computer technology, you can make rapid exchange of messages on the content of the service (Internet, e-mail, video conferencing). Modern sources with a powerful processor allows you to create qualitative programs aimed at improving textual information, photo, video modeling, audio tracking of CDs. The Internet is interacted with the global computer system and provide information to any topic. Its peculiarity from the encyclopedia is supplemented and updated here with new information. On the Internet, the student collects a lot of information in a short time. The student has a chance to study the topic until they are mastered, no time is limited [7, p. 140].

With the help of new information technologies (testing, training, diagnostic programs, simulators, electronic textbooks, etc.) can also be able to encourage their cognitive activities of learners. We considered opportunities to simplify the ability to learn different tasks for the determination of operative (emergency) testing, corrective methods, correctional methods, and tasks for determining the nature of errors in the development of material [8, p. 48].

\section{Research results}

In the distance learning, it is wrong to consider that it's eliminated interaction of students in the educational process. In some cases, it is very effective, because it is done taking into account everyone's capabilities. In explaining the new material, the teacher can organize debates and create discuss groups to communicate with the class. For these purposes, it is necessary to select the correct educational portal or create a high quality feedback using Messenger or Chat. You can create multiple tasks to perform in a group - a comprehensive problem task assignment with a shared project or role-play game, etc. All this can be done with the help of modern technologies.

During distance learning, the student has the right to self-assessment of language proficiency. The student finds his mistake and try not to repeat it. It is possible to do self-monitor in self-learning foreign language through information technology

Writing monitoring can seriously adjust the students to perform language tasks. Sometimes it is difficult to analyze the level of knowledge of every student. According to the results of monitoring, the student can see the results of two different activities. The first is his best aspects, the other will notice his shortcomings. Services for further development and shortcomings are used in managing the results of monitoring [9, p. 140].

The concept of «monitoring» means «observation». Undoubtedly, it is necessary to monitor for general education and experiment. With the help of monitoring, we can see the first level and the last level of students. Monitoring information serves us to promote students' ability and knowledge. We can repeat this approach several times to achieve the goal. In the process of teaching English, teachers should take into account each student's personal possibility. Implementation of this goal should take into account the student's interest, order, use, aspiration, understanding of the pursuit [10, p. 110-120].

With the help of the Online Mektep platform held a lesson to the 2nd grade of secondary school. The platform is aimed at presenting a new lesson, the introduction of new lexical materials, to improve the phonetical skills of students, to approve the lexicon in the early stages of education. The 
introduction and phonetic process of vocabulary is associated with different colorful attractive animations and gives opportunity to improve the phonetic training and to prepare them several times. Phonetic exercises can also be held with this platform. It is used individually and chorus training during the lesson. The feedback was sent through Classtime platform. This is an effective service (quiz, true / false, classification, text classification, sorting, choice) in controlling the learning process. As a result, the student's knowledge was determined and phonetically the new vocabulary was learned.

In the distance learning process, the teacher should use all the opportunities. Online lesson was organized to the level of "Beginner" through the ZOOM platform. According to the thematic plan the theme was "Food" (dishes). The advantages of this multimedia manual have been granted to the form of interactive space travel to control and approve the contents, audio, exercise, lexical knowledge to learn its content. All tasks are provided with colorful attractive animations and sound accompaniment. It is taken a certain text as an object and returned to it in several activities. This is a very interesting way to learn students in individual intellectual activity. Pupils provide an interactive dialogue with a computer character and provide a certain level of psychological situation.

It is necessary to take into account the purpose of education:

- Development of students' personal abilities, increasing its intentional activity, prosperity of internal intellectual potential.

- educational orientation of students [11, p. 76].

Different tasks are obtained for each monitoring. The tasks should be created according to course plan. In addition, each monitoring includes grammatical and lexical tests. The test task is created to the minimum level. The text of the task must be given with the instructions and explanations, terms of time, the assessment percentage, the number of questions.

Information technology can be used in teaching English language in the following main areas: automated, teaching systems; teacher, fastening and evaluator programs: for the purpose of presenting the program (electronic textbooks); demonstration programs, computer laboratory works (electronic laboratories); computer business games, simulators, simulation and modeling programs, supervisory computer programs, etc. [12, p.120].

The teacher is an instrument that organizes independent work of students and especially in the process of training with language and speech. It determines the nature of the exercises and methodological approaches to use. The following is often used:

1. Question-answer dialogue. The essence of the learner's work is to give direct answers to computer questions, using the language material written in the question as a basis and scheme.

2. Dialogue with a partial answer. To respond to the computer, the learner chooses one of the suggested options.

3. Dialogue with a freely constructed answer. The program provides such a dialogue with all possible options for answering each question asked by the computer so that the computer can "recognize" and evaluate the correctness of the answer.

4. Exercises to fill in the blanks. The computer provides the learner with a text or set of suggestions with spaces. Fill in the blanks using a whisper in the form of Russian words that need to be translated into a foreign language and used as needed. You can also choose from computer suggestions and fill in the blanks with words or phrases.

5. Exercises for self-monitoring of vocabulary. Variants of such exercises are possible:

a) The computer provides a list of words for translation;

b) The computer determines the relationship between two lists of words (Russian and foreign) and suggests to find alternative pairs of these words in two languages;

c) The computer suggests to determine the relationship between two lists of foreign words and to identify pairs of synonyms and antonyms;

d) The computer provides a list of foreign words and a definition of these words [13, p. 130].

One of the most widely used computer programs for learning English is "EUROTALK" or "Learn English" [14]. 
The content of these programs includes sections: introduction words, food, colors, concepts, body, numbers, time, consumer goods and products, countries. Each section consists of five sections: listening to the word; phonetic exercises, training games; difficult game; image of the word. All sections are interesting and informative for the learner. This program is especially important in teaching students. As they play, they learn the names of individual objects and concepts. In addition, the animation of the words helps to make the memory process more efficient and faster. Its main stages are: 1) memorization of the word, 2) check of vocabulary knowledge, 3) check of correct spelling of the word, 4) processing of sounds, 5) recording of sounds, 6) checking it. As a result of the use of this program, we noticed an increase in students 'cognitive and action interests, the development of students' skills of independent work, an increase in vocabulary.

\section{Conclusion}

The use of information technology in the process of distance learning has had a significant impact on the development of students' cognitive interests, which is especially evident in the practice of teaching English. In the process of performing the task, the student's thinking activity, the student's knowledge, research and spiritual skills, independent search, social understanding, interest in subject are developed.

In short, new information technologies - computer programs, e-textbooks, the internet provide abundant opportunities for students to learn English on their own, and it's one of the most effective ways to achieve this goal. Nowadays, the scope of education is expanding, the content and methods of teaching are changing, and the use of e-learning tools in the system of distance education shows that it is the only way to develop students' creative activity.

\section{REFERENCES}

[1] Karaev Zh.A., Esbosynov E.E., Balafanov E.K (1998). Analiz tendencija razvitija distancionnogo obrazovanija [Analysis of the development trend of distance education].// Vysshaja shkola Kazahstana. - 6 [in Russian].

[2] Dmitreva V.F., Gladskoj V.I., Rjabov V.A. (1996) Distancionnoe obuchenie: sushhnost', problema vnedrenija [Distance learning: essence, implementation problem] // Specalist'. - 7 [in Russian].

[3] Andreev A.A. (1999) Didakticheskie osnovy distancionnogo obuchenija v vysshih uchebnyh zavedenijah [Didactic Basics of Distance Learning in Higher Educational Institutions]. Extended abstract of candidate's thesis. - Moskva [in Russian].

[4] Andreev A.A., Soldatkin V.I. (1997) Distancionnoe obuchenie: sushhnost', tehnologija, organizacija. [Distance learning: essence, technology, organization] - M.: Izdatel'stvo MJeSI [in Russian].

[5] Abykanova B.T. (2005) Komp'juterlik tehnologijany pajdalanu arkuly okushylardyn tanymdyk belsendiligin arttyrudyn didaktikalyk sharttary [Modully technologies in the system of Credditization of students]. Almaty [in Kazakh].

[6] GershunskijB.S. (2002) Kachestvo obrazovanija // Filosofija obrazovanija dlja XXI veka. - [Philosophy of education for the XXI century.] Moskva [in Russian].

[7] Temirbekova Zh.A. (2008) Studentterdin kredittik oku zhujesindegi modul'dik tehnologija arkyly okytu didaktikasy («inzhenerlik syzba» pəninegizinde). [Didactics of teaching students through modular technology in the credit system of education (based on the discipline "Engineering Drawing")] Extended abstract of candidate's thesis. Pavlodar [in Kazakh].

[8] Karaev Zh.A. (1994) Aktivizacija poznavatel'noj dejatel'nosti uchashhihsja v uslovijah primenenija komp'juternoj tehnologii obuchenija: [Activation of cognitive activity of students in the conditions of application of computer technology of training] Extended abstract of candidate's thesis - Almaty [in Russian].

[9] Koshimbetova S.A. (2004) Oku-tarbie urdisinde okytudyn innovacijalyk adis təsilderin pajdalanudyn pedagogikalyk sharttary [Pedagogical conditions for the use of innovative methods of teaching in the educational process]. Extended abstract of candidate's thesis. Almaty [in Kazakh]. 
[10] Lerner I.J. (1981) Didakticheskie osnovy metodov obuchenija, - [Didactic base methods]: Pedagogika, Moskva [in Russian].

[11] Sadykov T.S. (2006) Informacionno-obrazovatel'noe pole $v$ sisteme nepreryvnogo obrazovanija RK [Information and educational field in the system of continuous formation of RK]. Almaty [in Russian].

[12] Fircov V.V. (1994) Differenciacija obuchenija na osnove objazatel'nyh rezul'tatov obuchenija. [Differentiation of learning based on mandatory learning outcomes] Moskva: Nauka [in Russian]

[13] Hmel' N.A. (2003) Birtutas pedagogikalyk procesti zhuzege asyrudyn teorijasy men tehnologijasy: оқ̧и kuraly [Theory and technology of hitting a single Peargogical puke] - Almaty [in Kazakh].

[14] Euro talk Nachnite govorit' prjamo sejchas (1999) - interaktivnoe posobie dlja izuchenija anglijskogo jazyka.

\section{Нұрқашева Ф.P. \\ ҚАШЫҚТЫҚТАН БІЛІМ БЕРУ КЕЗІНДЕГІ АҒЫЛШЫН ТІЛІН ҮЙРЕНУДЕ КОМПЬТЕРЛІК ТЕХНОЛОГИЯНЫН МАНЫЗЫ}

Андатпа. Әлемдік білім кеңістігіне етене таныс қашықтықтан білім беру үрдісі еліміздегі басты бағыт болып отыр. Қашықтықтан білім беруді тиімді ұйымдастырып белгілі бір нәтижеге жету мәселесі өзекті. Мақалада заманауи білім беру процесінде қашықтықтан оқыту үрдісінде ағылшын тілін оқытуда машықтармен құзыреттіліктерді қалыптастырудың маңыздылығы зерделенген. Ақпараттық-коммуникативтік құралдардың тіл үйренудегі артықшылықтыры көрсетілген. Қашықтықтан оқытудың негізгі компоненттері қысқаша баяндалып, компьютерлік технологияның қасиеттерінің білім берудегі тиімді тұстары қарастырылған. Қашықтықтан білім беру барысындағы мониторинг ұғымы және оның орта мектеп оқушылары үшін өз - өзін бағалаудағы маңызы көрсетілген. Қашықтықтан оқыту үрдісіндегі оқыту платформаларының көмегімен жасалған сабақтардың тапсырмалары, мүмкін болатын жаттығулар мен олардың нәтижелері сараланған. Тілді оқытуда тиімді болып табылтын компьютерлік бағдарламаларға шолу жасалып, ерекшеліктері дәлелденген.

Кілт сөздер: қашықтықтан оқыту, электрондық оқыту технологиясы, электрондық ресурстар, компьютерлік бағдарлама, мониторинг, оқыту платформалары.

\section{Нуркашева Ф.Р. \\ ВАЖНОСТЬ КОМПЬЮТЕРНЫХ ТЕХНОЛОГИЙ В ИЗУЧЕНИИ АНГЛИЙСКОГО ЯЗЫКА ПРИ ДИСТАНЦИОННОМ ОБУЧЕНИИ}

Аннотация. Процесс дистанционного обучения является основным направлением во всем мире. В настоящее время вопрос об эффективной организации дистанционного образования и достижения определенных результатов в этом направлений очень актуален. В статье изучалась важность формирования навыков и компетенции в преподавании английского языка в процессе дистанционного обучения в современном образовании. Показаны преимущества информационно - коммуникативных средств в изучении языка. Представлена важность концепции мониторинга во время дистанционного обучения и его большое значение для учеников средней школы при самооценке. Обобщены основные компоненты дистанционного обучения и рассмотрены свойства компьютерных технологий для эффективного преподавания. Дифференцированы уроки и их результаты на учебных платформах в процессе дистанционного обучения. Был произведен обзор компьютерных программ в обучении языка и доказаны их эффективность.

Ключевые слова: дистанционное обучение, технологии электронного обучения, электронные ресурсы, мониторинг, учебные платформы. 